University of Nebraska - Lincoln

DigitalCommons@University of Nebraska - Lincoln

Marketing Department Faculty Publications

Marketing Department (CBA)

$7-2004$

\title{
The Role of Relational Knowledge Stores in Interfirm Partnering
}

Jean L. Johnson

Washington State University

Ravipreet S. Sohi

University of Nebraska-Lincoln, ravisohi@unl.edu

Rajdeep Grewal

Pennsylvania State University - Main Campus

Follow this and additional works at: https://digitalcommons.unl.edu/marketingfacpub

Part of the Business Administration, Management, and Operations Commons, Marketing Commons, and the Strategic Management Policy Commons

Johnson, Jean L.; Sohi, Ravipreet S.; and Grewal, Rajdeep, "The Role of Relational Knowledge Stores in Interfirm Partnering" (2004). Marketing Department Faculty Publications. 22.

https://digitalcommons.unl.edu/marketingfacpub/22

This Article is brought to you for free and open access by the Marketing Department (CBA) at DigitalCommons@University of Nebraska - Lincoln. It has been accepted for inclusion in Marketing Department Faculty Publications by an authorized administrator of DigitalCommons@University of Nebraska - Lincoln. 
Jean L. Johnson, Ravipreet S. Sohi, \& Rajdeep Grewal

\section{The Role of Relational Knowledge Stores in Interfirm Partnering}

Drawing on the notions of relational capabilities and absorptive capacity, the authors examine the effects of interactional, functional, and environmental knowledge stores on relationship quality and relationship portfolio effectiveness. The results suggest that the knowledge stores affect the outcome variables differently and that the effects vary by levels of industry turbulence.

$\mathbf{0}$ ver the past decade, concepts pertaining to knowledge acquisition and development by firms (i.e., organizational learning) have assumed an important role in the understanding of how firms succeed. A reason for the enthusiastic interest in knowledge acquisition and management could be the close relationship between a firm's knowledge stores and its capabilities or competences (e.g., Eisenhardt and Martin 2000; Leonard-Barton 1992; Winter 1987, 2000). Given the widely acclaimed strategic significance of capabilities that derive from a firm's knowledge stores, particularly complex stores that are deeply embedded and difficult to observe or imitate, knowledge can result in competitive advantage and superior performance (e.g., Eisenhardt and Martin 2000; Teece, Pisano, and Shuen 1997). Indeed, many firms allocate substantial resources to knowledge development and management. For example, General Motors has implemented a companywide learning system that enables adaptation to market conditions. The mutual insurance company USAA has designed and implemented a knowledge system that enables the company to manage its strategic initiatives. Kraft Foods has created a knowledge system that enables expenditures to be redeployed to high-value activities. Ocean Spray has implemented a marketing-knowledge repository that provides marketplace information to managers. Finally, Toyota has created a knowledge-sharing network with suppliers to facilitate learning (Dyer and Nobeoka 2000; Slotegraaf 1999). Beyond these, other examples of firm-level learning efforts abound.

Recognizing that knowledge is fundamental to building capabilities, scholars have emphasized the role of organizational learning and knowledge management in marketing (e.g., Day 1994, 2000; Glazer 1991; Sinkula 1994; Slater and Narver 1995). In terms of empirical work, some

Jean L. Johnson is Professor of Marketing, Washington State University (e-mail: johnsonjl@wsu.edu). Ravipreet S. Sohi is Associate Professor of Marketing, University of Nebraska (rsohi1@unl.edu). Rajdeep Grewal is Assistant Professor of Marketing, Smeal College of Business Administration, Pennsylvania State University (rug2@psu.edu). The authors thank Christine Moorman for her helpful suggestions during the development phase of the manuscript. Funding for this project was provided by the University of Nebraska's Layman Research Grant Fund. researchers have investigated the role of knowledge and learning in new product development processes $(\mathrm{Li}$ and Calantone 1998; Madhavan and Grover 1998; Moorman and Miner 1997). Others have examined learning in the context of market information processing (Hult and Ferrell 1997) and indirectly in market and learning orientations (Baker and Sinkula 1999; Hurley and Hult 1998; Sinkula, Baker, and Noordewier 1997). Although learning and knowledge are believed to play a significant role in interfirm relationships (Dyer and Singh 1998), work in this area is limited to a few conceptual articles (e.g., Lukas, Hult, and Ferrell 1996; Mohr and Sengupta 2002). The broad objective of this article is to extend this stream of research by empirically examining the role of knowledge stores in buyer-seller interfirm relationships (IRs).

Scholars have suggested that IRs often serve as strategic assets and, as such, firms should try to develop the ability to manage them accordingly (Day 1994, 2000; Dyer and Singh 1998; Jap 1999, 2001; Johnson 1999; Srivastava, Shervani, and Fahey 1998). This vital ability, referred to as a firm's "relational capability" (Dyer and Singh 1998), is based on the creation of knowledge stores (Winter 1987, 2000). Although relational capability is strategically crucial, little is known about how it is developed and used, particularly in the turbulent conditions that typify the business environment that many firms face today. Realization of any potential advantage of relational capability requires an understanding of the processes involved in developing the relevant knowledge that underpins it and the use of that knowledge across different environmental conditions.

In this article, we suggest that IR knowledge stores develop from a firm's absorptive capacity (Cohen and Levinthal 1990). Furthermore, because the garnering of superior outcomes is a primary impetus for learning and capabilities development, we examine the effects of IR knowledge on relationship outcomes. We focus on two such outcomes. First, we examine the effects of IR knowledge on relationship quality (e.g., Hibbard, Kumar, and Stern 2001). Second, we investigate the impact of knowledge stores on relationship effectiveness across the firm's IR portfolio (Cannon and Perreault 1999). Given that firms often operate in an ever-changing environment, we also investigate the moderating effect of environmental turbulence. 


\section{Conceptual Framework}

Relational capability involves a firm's learned ways of behaving in its IRs, including procedures and policies in IR management. The development and manipulation of knowledge stores is integral to the creation of relational capability (e.g., Day 1994; Dyer and Singh 1998; Leonard-Barton 1992). To develop knowledge stores for the socially complex and deeply embedded routines that constitute relational capability, firms actively engage in learning at the organizational level (Collis 1994; Nonaka 1994; Winter 2000). Over the past decade, various perspectives have been presented on organizational learning, including ones that conceptualize learning as the process of gathering, disseminating, and interpreting information (e.g., Sinkula 1994; Slater and Narver 1995). These works, which focused on information and its use and integration in the firm, have been particularly useful in learning about markets and market responses (e.g., Li and Calantone 1998). A complementary perspective on learning that has received considerable attention in the organizational literature (Lane, Koka, and Pathak 2002), and one that readily lends itself to the explanation of capabilities development, is that of absorptive capacity (Cohen and Levinthal 1990).

Absorptive capacity depicts learning as the processes by which a firm derives and absorbs knowledge from its experiences and actions (e.g., Cohen and Levinthal 1990; Lane and Lubatkin 1998; Zahra and George 2002). At an abstract level, absorptive capacity has been defined as a firm's ability or capability to build and upgrade knowledge stores. An important implication of the absorptive capacity perspective is that it assumes that there is some preexisting level of knowledge. Absorptive capacity describes how knowledge develops cumulatively and builds on prior knowledge stores (Cohen and Levinthal 1990). Firms that have prior relevant knowledge are better able to acquire and assimilate new knowledge. The three central components of absorptive capacity are (1) an understanding of new information based on the accumulation of observations and cues from experiences, (2) assimilation and integration of the information into knowledge stores, and (3) application of the knowledge (Cohen and Levinthal 1990; Lane, Salk, and Lyles 2001).

Absorptive capacity provides the theoretical framework for our conceptual model, which is shown in Figure 1. Firms come to terms with new information and assimilate it into knowledge stores through sensemaking, wherein meaning is assigned to observations and cues in situations, events, and occurrences (Weick 1995). Knowledge emerges from offline or retrospective processing that is involved in sensemaking because it reorganizes and creates order from discrepant observations and cues. Here, we focus particularly on the knowledge-application phase of absorptive capacity. We expect that when IR knowledge is developed, it can be applied in interfirm relationships to enhance their individual quality and effectiveness as a group.

\section{IR Knowledge Stores}

Knowledge stores in IRs are a firm's reservoirs of collective insights, beliefs, behavioral routines, procedures, and poli-

FIGURE 1

Model Depicting Conceptual Framework and Hypothesized Relationships

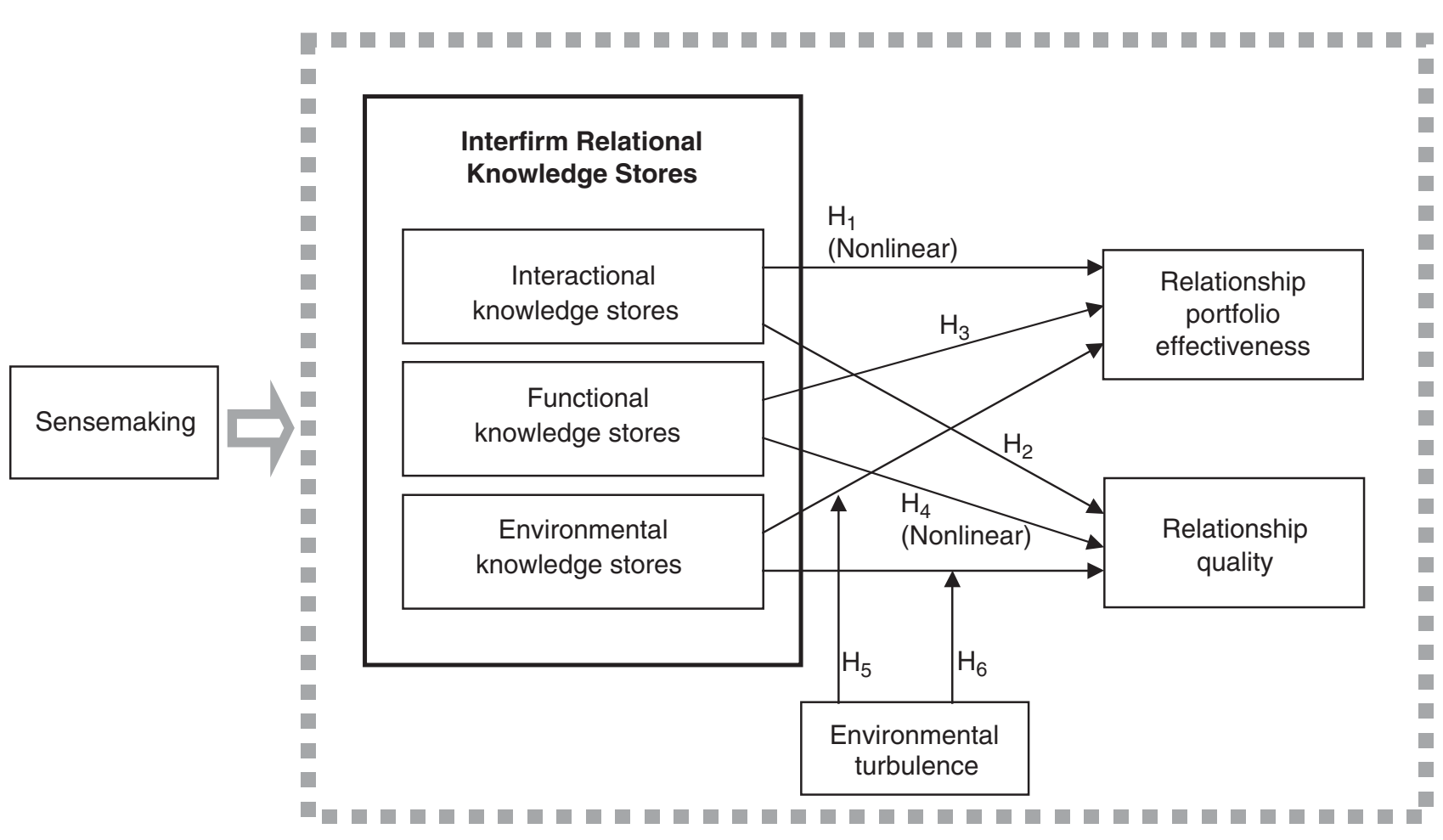


cies in IR management (Day 1994; Walsh and Ungson 1991). When firms form strategic relationships with a few suppliers instead of arm's-length transactions with many suppliers (e.g., Anderson and Weitz 1992; Celly, Spekman, and Kamauff 1999; Ganesan 1994; Watts, Kim, and Hahn 1992), the role of knowledge related to interactions and relational dynamics becomes extremely important. Firms also must manage the functional components in the IR, such as costs, quality, delivery, and inventory aspects in the supply chain. Indeed, relationship management and supply chain management have been proposed as core business processes (Lehmann and Jocz 1997; Srivastava, Shervani, and Fahey 1999), which makes knowledge about the processes crucial to company success. Prior research also points to the need to study environmental conditions (e.g., Achrol, Reve, and Stern 1983). A preponderance of the strategy literature suggests that to be successful, firms need to identify and adapt to the environmental conditions (Moorman and Slotegraaf 1999). Firms' IRs serve as antennas that scan their environments and act as sources of information on various aspects, including the competitive environment (e.g., Celly, Spekman, and Kamauff 1999). Firms' IRs also serve as mechanisms for coping with the environment (e.g., Achrol and Stern 1988; Dwyer and Welsh 1985), which makes knowledge about the environment another crucial component of IR knowledge stores. On the basis of this and exploratory interviews with managers, we consider three important subdomains of IR knowledge in this study: (1) interactional knowledge stores, (2) functional knowledge stores, and (3) environmental knowledge stores.

Interactional knowledge stores. Interactional knowledge stores consist of knowledge about issues related to interactions in partner relationships. Interactional knowledge includes aspects such as communication, negotiation, conflict management, and development and implementation of cooperative programs (e.g., Ganesan 1993; Heide and John 1990; Mohr, Fisher, and Nevin 1996; Murry and Heide 1998). Interactional knowledge stores reflect the sociopsychological components of IRs.

Functional knowledge stores. Functional knowledge stores consist of a firm's knowledge about issues related to the management of supply chain functions. Functional knowledge includes working with suppliers in areas such as cost reduction, quality control, operations and production, logistics and delivery, inventory management, and product development (e.g., Frazier, Spekman, and O’Neal 1988; Klein, Frazier, and Roth 1990; Srivastava, Shervani, and Fahey 1999).

Environmental knowledge stores. Environmental knowledge stores consist of a firm's knowledge about its external operating environment. Environmental knowledge stores include factors in the secondary and macro task environments, such as competitive behavior, market conditions, and variations in laws and regulations (e.g., Achrol and Stern 1988; Dwyer and Welsh 1985; Grewal and Dharwadkar 2002).

\section{Hypotheses}

In this study, we examine the effects of each IR knowledge store on two forms of strategically desirable relational outcomes. First, we consider the effect of IR knowledge on relationship quality, which is a higher-order construct composed of three dimensions: trust, commitment, and stability (e.g., Hibbard, Kumar, and Stern 2001; Jap 1999). Second, we consider the influence of IR knowledge on the effectiveness of a firm's IR portfolio. Despite their advantages, not all IRs can or should be close and collaborative (e.g., Cannon and Perreault 1999; Frazier 1999); certain relationships simply may not merit the resources required to maintain them, "partner" firms may prefer arm's-length arrangements, or transaction characteristics may make market governance more effective (e.g., Williamson 1996). Thus, outcomes of IR knowledge extend beyond individual IRs to include portfolio perspectives in which IR effectiveness is considered as a group. We expect that the various dimensions of IR knowledge (interactional, functional, and environmental) influence the two outcomes in complex ways.

\section{Effects of Interactional Knowledge Stores}

A firm's portfolio of relationships may vary from arm'slength, transaction-based arrangements to close, collaborative partnerships (Cannon and Perreault 1999; Frazier 1999). Given the extent to which interactional issues (e.g., planning and managing partnering activities, negotiating, managing conflict) pervade and extend over the range of a firm's IRs, knowledge gained in any one IR may be applied to others. Because of these transferability and knowledge spillover effects (Uzzi and Gillespie 2002), interactional stores should increase the effectiveness of a firm's relationship portfolio. Furthermore, we expect that this increase is nonlinear because interactional knowledge stores can potentially generate positive feedback effects with respect to portfoliowide effectiveness, which should manifest in the accrual of returns at an increasing rate. Positive feedback effects are self-reinforcing mechanisms that enhance outcomes through learning, coordination, and/or scale effects (Arthur 1994; Dickson, Farris, and Verbeke 2001). For example, a firm with strong negotiation skills can apply the skills in all negotiating activities across its relationship portfolio for significant payoffs in multiple relationships. Thus, we suggest the following:

$\mathrm{H}_{1}$ : The effect of interactional knowledge stores on the general effectiveness of IRs is positive and nonlinear; greater levels of interactional knowledge stores increase the effectiveness of the IR portfolio at an increasing rate.

Interactional knowledge stores are instrumental in the identification and facilitation of the development of behaviors and properties that are desirable in close, partner-style IRs (e.g., Ford and McDowell 1999; Morgan and Hunt 1994). Interactional knowledge-such as that involved in negotiating with suppliers, planning and managing IR activities, implementing cooperative programs, and managing conflict — can be key in building trust and commitment in a relationship (Crosby, Evans, and Cowles 1990; Morgan and Hunt 1994; Stern, Sternthal, and Craig 1973; Sullivan et al. 1981). Firms can also use effective interactional knowledge 
to build strong bonds with a partner, thereby providing stability to a relationship (e.g., Anderson and Weitz 1992). However, because trust, commitment, and stability are idiosyncratic to each relationship, the transference and feedback effects of interactional knowledge are limited and nonmultiplicative. Therefore:

$\mathrm{H}_{2}$ : The level of interactional knowledge stores positively influences relationship quality.

\section{Effects of Functional Knowledge Stores}

Firms garner functional knowledge stores by investing in a relationship through programs and activities such as total quality management (TQM), just-in-time (JIT) systems, or product codevelopment. In the process, a firm develops a deep understanding of its partner's (e.g., its supplier's) way of doing business, of its resources and objectives, and of the supplier firm in general. In this respect, it is not practical or even desirable to invest in and develop such deep understanding for all suppliers. Even when TQM, JIT, or other similar programs are desirable for a supplier, some adaptation of the program is needed to accommodate the uniqueness from supplier to supplier. Thus, because of the unique properties of the functional knowledge stores, and because of the type of relationships in which these stores develop and come into play, they are somewhat more limited in their generalizability than are the other IR knowledge stores.

Despite this, some expertise and skill can be reasonably applied across the firm's portfolio of relationships, because in developing rich functional knowledge stores, a firm has a greater understanding of what can and should be accomplished throughout its IR portfolio in terms of functions and cost reduction. With rich functional knowledge stores in place, the firm has a platform from which it can effectively adapt and extend its knowledge. For example, developing effective interfirm TQM programs with a supplier provides the firm with a point from which to develop TQM programs with others, even though the programs may not be the same. Thus, we expect the following:

$\mathrm{H}_{3}$ : The level of functional knowledge stores positively influences the overall effectiveness of the IR portfolio.

Functional knowledge stores imply that a buyer builds knowledge from working closely with individual suppliers in areas such as cost reduction, new product development, and quality improvements and from integrating a supplier in the buyer's JIT and extranet systems. A firm's building of this knowledge store mandates resource utilization in order to understand its partner's objectives, needs, and ways of doing business. As a result, the knowledge accumulated is often proprietary and, relative to the other components of IR knowledge, specific to that partner firm. However, when functional knowledge stores have been acquired, they enable a firm to leverage facets of the supply chain and to provide increased returns for the partner (Srivastava, Shervani, and Fahey 1999), thereby enhancing the quality of the relationship between the firms. For example, a firm may invest in developing a TQM program with a partner firm. When the program is in place, the benefits accrue continually, which further strengthens the relationship between the firms (e.g., Douglas and Judge 2001; Flynn, Sakakibara, and Schroeder 1995) and enhances relationship quality at an increasing rate. Thus, positive feedback effects due to localized learning are set in motion (Dickson, Farris, and Verbeke 2001). Therefore, we hypothesize the following:

$\mathrm{H}_{4}$ : The effect of functional knowledge stores on relationship quality is positive and nonlinear; greater levels of functional knowledge stores increase relationship quality at an increasing rate.

\section{Effects of Environmental Knowledge Stores}

It is important for firms to manage the uncertainty that stems from the environment (Achrol, Reve, and Stern 1983; Achrol and Stern 1988; Dwyer and Welsh 1985). Environmental knowledge stores help a firm recognize environmental contingencies and develop its IR portfolio to manage them (e.g., Cannon and Perreault 1999). Based on the environmental conditions, these knowledge stores enable a firm to recognize and assemble an array of relationships, some of which provide flexibility and ease of dissolution when needed and others that provide the advantages of close, partner-style IRs. Consistent with the open-systems perspective (e.g., Achrol, Reve, and Stern 1983), these knowledge stores are geared toward helping firms manage their environment by configuring the optimal IR portfolio. However, the effectiveness of these knowledge stores depends on the degree of environmental turbulence. In stable environments, organizations are less likely to change their patterns of behavior (Mintzberg and Waters 1985). However, in turbulent environments, previous patterns of behavior are less informative, and firms must draw on their environmental knowledge stores to guide their actions with respect to reconfiguring and managing the IR portfolio. Thus, an increase in environmental turbulence enhances the positive effect of environmental knowledge stores on IR portfolio effectiveness, which suggests an interaction effect:

$\mathrm{H}_{5}$ : Environmental turbulence moderates the effect of environmental knowledge stores on the overall effectiveness of the IR portfolio; the positive effect strengthens as environmental turbulence increases.

Scholars have argued that individual IRs provide buffers and are an effective means for firms to cope with environmental uncertainty (e.g., Achrol 1991). In the context of buyer-seller interactions, when environmental conditions vary, firms tend to develop closer relationships with partner firms because close relationships create flexibility, which enables the dyadic partners to adapt and negotiate adjustments mutually (Noordewier, John, and Nevin 1990). Furthermore, when environmental demands and practices are constantly changing, close relationships facilitate communication and coordination across the dyad (Jap 1999). Sometimes, firms also establish close relations with supplier firms, especially in international markets, to create supply stability and to have access to the resources they need (Keister 1999). Environmental knowledge stores facilitate the creation of close relationships because they enable a firm to recognize and communicate environmental contingencies to partners. Thus, we expect that environmental knowledge stores positively affect relationship quality, but the effect depends on the degree of environmental turbulence. When the environment is stable, firms have little 
need to draw on these knowledge stores. However, in turbulent environments, the need and value of the knowledge stores increase. Thus, we posit the following:

$\mathrm{H}_{6}$ : Environmental turbulence moderates the effect of environmental knowledge stores on relationship quality; the positive effect strengthens as environmental turbulence increases.

\section{Methods}

\section{Questionnaire Development and Pretesting}

We based the measures developed for this study on the academic and practitioner literature and on field interviews. These sources provided the foundation for construct item pools, which were subjected to several iterations of peer review by experts in the field. After a satisfactory conclusion on the item pools, the completed research instrument was again peer reviewed with format, appearance, and flow as the major focus. Next, we pretested the questionnaire through in-depth interviews with executives from four firms. In the interviews, we discussed the study objectives in general terms; after the pretest, subjects completed the questionnaire, and we debriefed them extensively. This pretesting approach was appropriate first because concerns regarding the sample size that, in general, are assessed through broader-based pretesting were addressed in our study by the extensive key-informant prescreening procedure we used. Second, given that several constructs in our study are new, we believed that we could isolate measurement and questionnaire format problems more effectively with in-depth interviews.

An important third concern in pretesting involved the transition between reporting tasks. Some elements of the questionnaire focused on a firm's supplier relationships in general, and other elements focused on a specific supplier relationship. To address this, we separated the two reporting tasks in the questionnaire. As a task-transition mechanism, a distinct section of the questionnaire focused attention on an individual relationship by asking respondents to identify a specific relationship and to report demographic and descriptive information on that relationship. Pretesting ascertained that the respondents indeed made the transition from general interfirm partnering tendencies to a specific supplier relationship without confusion. Our transition mechanism to change respondent focus was effective. In addition, all respondents completed the questionnaire in the expected amount of time and understood the instructions, reporting tasks, items, and language we used.

\section{Sample and Data Collection Procedures}

We collected data from a multi-industry mail survey that included the chemical and allied products, rubber and plastic products, metal fabrications and products, industrial machinery and equipment, electronic and electric equipment, and automotive and transportation equipment industries. As a preliminary step in the research process, we conducted several in-depth telephone and personal interviews with materials-acquisition executives in the industries. The results of the interviews implied that the research topic was relevant and compelling for the incumbent firms. In addition, the interviews suggested that the construct variance would likely be sufficient for testing the posited relationships.

We procured a list of firms from a commercial list source. After removing duplicate and incomplete addresses from the list, we had a sample of 781 firms for the project. The first step in data collection was a mail prescreening of potential respondents to assess their appropriateness and to determine whether they met the criteria of involvement and knowledgeability, as indicated by Campbell (1955). Using a short prescreening questionnaire, we determined their position with the firm, number of years in that position, and percentage of time spent on supplier-related activities. In addition, using seven-point scales, we assessed (1) the extent to which respondents were personally involved in supplier relationships and (2) how knowledgeable they were about their firm's dealings with suppliers. Of the 781 firms, we received prescreening responses from 330. Of these, we eliminated 11 because they were low on the knowledgeability and involvement criteria (i.e., scored lower than six on a seven-point scale), spent less than $70 \%$ of their time on supplier-related activities, were in their position less than two years, or were low-level purchasing personnel. The 319 remaining managers identified as appropriate key informants held titles including vice president or directors of operations, procurement, manufacturing, materials management, or supply processing.

Each of the 319 qualified potential respondents was mailed a packet that included a cover letter, the survey instrument, and a prepaid return envelope. As an incentive for participation in the study, we offered the respondents an executive summary. To overcome a possible selection bias of managers automatically reporting on the largest supplier, we used a $2 \times 2$ design and randomly assigned respondents to report on the following aspects of a supplier relationship: relationship duration of less than two years versus greater than two years and average versus crucially important components or products supplied in the relationship. Assignment to one of the four conditions resulted in reports on a diverse range of relationships for study (Ganesan 1994). As a cross-check for key informant validity, we also included the items we used for prescreening in the survey instrument. The initial mailing and one follow-up mailing generated 176 responses $(23 \%$ of the original sample and $55 \%$ of the qualified informants), of which 169 were usable. To check for nonresponse bias, we compared the respondents with nonrespondents on the prescreening questions, Standard Industrial Classification (SIC) codes, company sales volume, and number of employees. We then compared the early and the late respondents on demographic and model variables (Armstrong and Overton 1977). The t-tests showed no statistically significant differences, which suggests that response bias was not an issue in this study.

\section{Measures}

We used formative scales to assess the interfirm relational knowledge stores. The measures focused on the managers' perceptions of the content and level of IR partnering knowledge retained in the firm's memory (e.g., Moorman and 
Miner 1997). The responding executives rated the extent of knowledge that they believed their firms held, using a seven-point Likert scale anchored by $1=$ "very little knowledge" and 7 = "extensive knowledge." The measure of interactional knowledge stores consisted of five items that pertained to negotiating practices, planning and management of partnering activities, development and use of cooperative activities, computer networking with suppliers, and conflict management. We assessed functional knowledge stores with six items that consisted of cost reduction, product development, delivery time, quality management, inventory management, and production efficiency. For environmental knowledge stores, four items pertaining to laws and regulations, market conditions, labor conditions, and competitors' behaviors constituted the measure. The Appendix provides full detail on the measures in the study.

Relationship quality consisted of three dimensions: trust, commitment, and stability. The measure of trust consisted of six items that focused on, for example, partner honesty, reliability, and partner concern for the firm's welfare (Doney and Cannon 1997). We assessed commitment with a five-item scale that included issues such as loyalty, willingness to invest, and expectations of a long-term association (Anderson and Weitz 1992). For the trust and commitment measures, the responses ranged from $1=$ "strongly disagree" to $7=$ "strongly agree." We created a four-item bipolar adjective scale to assess relationship stability. For example, executives rated the extent to which their supplier relationship was insecure or secure on a seven-point scale.

The measure for relationship portfolio effectiveness, which we also created for this study, focused on perceptions about the firm's IRs as a group. Four statements constituted the scale. An example of the statements is, "Across the board, our supplier relationships operate well for us." Other items assessed productivity, efficiency and effectiveness, and the extent to which the IRs met the firm's needs as a group or portfolio. Executives responded in terms of whether they agreed or disagreed with the statements on a seven-point scale.

We based the environmental turbulence measure on secondary data. We used trade literature, government documents, and popular business press (e.g., The Wall Street Journal, Business Week) to gather information on technological change, innovation, significant new product introduction, growth or decline in markets, competitive and industry structure changes (e.g., mergers, acquisitions, alliances, number of firms leaving or entering, changes in market shares or concentration ratios), legal or regulatory changes, and other factors that we judged as part of the relevant environment. On the basis of the information, we used a Delphilike iterating approach to develop the scale using the following procedure: (1) A team of MBA students compiled environmental turbulence reports for each industry; (2) the reports were shared across the six industry teams; (3) using a scale that ranged from one (least turbulent) to six (most turbulent), each team evaluated the turbulence level for each industry; (4) the teams paired up to reevaluate and reconcile their ratings; (5) the pairs of teams were then joined by another pair of teams, and they reconciled the turbulence ratings again; and (6) the remaining two teams joined and again reconciled the ratings to reach a final consensus for the scale. Table 1 provides detail on the environmental turbulence scale.

Although we did not formally hypothesize a role for the sensemaking construct, we expect that it acts as a covariate with regard to knowledge application. Thus, we operationalized it on the basis of Weick's (1995) conceptualization. The measure consisted of five items that focused on sensemaking by boundary-spanning materials-acquisition executives in IRs (e.g., "In our supplier relationship, we constantly assess and analyze the effects of our decisions so that we know what adjustments to make"). Other items addressed firms' identifying and understanding mistakes, understanding successful activities and programs, and understanding the effects of actions and decisions and various adjustments to them in the relationship. Respondents indicated the extent of their disagreement or agreement on a seven-point scale (1 = "disagree," 7= "agree").

\section{Results}

\section{Measure Validation}

We used confirmatory factor analysis (CFA) for measure validation. The $\chi^{2}$ for the model of all the first-order reflective constructs was 447.86, with 242 degrees of freedom. The comparative fit index (CFI), normed fit index (NFI), and nonnormed fit index (NNFI) were .97, .94, and .97, respectively. The ranges of loadings for each measure as well as construct reliabilities and average variance extracted (AVE) are shown in the Appendix. Construct reliabilities were .91 or greater, exceeding the benchmarks that are suggested as acceptable (Nunnally and Bernstein 1994); AVEs were greater than .72. All the indicators loaded significantly and substantively on their hypothesized factors $(p<.001)$. To test for discriminant validity, we ran a series of nested CFA model comparisons in which we constrained the covariance between each pair of reflective constructs to one (Anderson and Gerbing 1988). For all pairs, when we compared the constrained model with a free model, the difference was significant, which indicates discriminant validity. We also examined the variance extracted by each construct relative to the squared correlation between construct pairs (Fornell and Larcker 1981). In all cases, the variance extracted by each factor exceeded the squared correlation between the factor pair, thus indicating discriminant validity.

We developed the measures of the three knowledge stores as formative (Diamantopoulos and Winklhofer 2001; Edwards and Bagozzi 2000). Thus, the precision and thoroughness with which we established and tapped (content validity) the construct domains provided the major validation tool (Howell 1987). Our procedures in the preliminary stages of research, interviews, and pretesting, along with visual inspection of the scale items, provided evidence of content validity. This procedure, along with the CFA results for the reflective measures, suggests that all the measures in this study are adequately reliable and valid.

We estimated a second-order CFA for relationship quality, because we conceptualized it as a higher-order construct that comprised trust, commitment, and stability. The target 
TABLE 1

Turbulence Classifications and Sample Characteristics

\begin{tabular}{|c|c|c|c|c|c|c|c|c|}
\hline $\begin{array}{l}\text { Industry and SIC } \\
\text { Range }\end{array}$ & $\begin{array}{c}\text { Turbulence } \\
\text { Level }\end{array}$ & Nature of Turbulence & $\begin{array}{l}\text { Average } \\
\text { Dollar } \\
\text { Sales/ } \\
\text { Revenues } \\
\text { (in Millions) }\end{array}$ & $\begin{array}{l}\text { Average } \\
\text { Relationship } \\
\text { Length }\end{array}$ & $\begin{array}{c}\text { Average } \\
\text { Number of } \\
\text { Other } \\
\text { Suppliers } \\
\text { for } \\
\text { Product } \\
\text { Category }\end{array}$ & $\begin{array}{c}\text { Average } \\
\text { Percentage } \\
\text { of Product } \\
\text { Category } \\
\text { Purchased } \\
\text { from This } \\
\text { Supplier }\end{array}$ & $\begin{array}{l}\text { Average } \\
\text { Percentage } \\
\text { of Total } \\
\text { Purchases } \\
\text { from This } \\
\text { Supplier }\end{array}$ & $\begin{array}{c}\text { Average } \\
\text { Percentage } \\
\text { of Supplier's } \\
\text { Sales } \\
\text { Accounted } \\
\text { for by This } \\
\text { Relationship }\end{array}$ \\
\hline $\begin{array}{l}\text { Metal fabrications and } \\
\text { products, 3411-3499 }\end{array}$ & $1(n=6)$ & $\begin{array}{l}\text { In general, stable on most } \\
\text { dimensions; moderate technology } \\
\text { change; relative stability in } \\
\text { competitive activity, composition, } \\
\text { and demand }\end{array}$ & $\$ 229.0$ & 14.2 & 4.5 & $65 \%$ & $39 \%$ & $13 \%$ \\
\hline $\begin{array}{l}\text { Industrial machinery } \\
\text { and equipment, } \\
\text { 3511-3599 }\end{array}$ & $2(\mathrm{n}=41)$ & $\begin{array}{l}\text { Reasonable new product } \\
\text { introduction; innovation incremental } \\
\text { in most sectors; relative stability in } \\
\text { industry composition, competitive } \\
\text { activity, and demand }\end{array}$ & 33.6 & 14.1 & 6.2 & 66 & 40 & 18 \\
\hline $\begin{array}{l}\text { Chemical and allied } \\
\text { products, } 2812-2899\end{array}$ & $3(n=26)$ & $\begin{array}{c}\text { New product introduction and } \\
\text { innovation significant in some } \\
\text { sectors, reasonably intense } \\
\text { competition, some alliances, } \\
\text { relatively stable demand }\end{array}$ & 26.6 & 11.0 & 3.0 & 78 & 58 & 13 \\
\hline $\begin{array}{l}\text { Rubber and plastics, } \\
3011-3069\end{array}$ & $4(n=22)$ & $\begin{array}{c}\text { Reasonable rates of innovation and } \\
\text { new products, relatively few new } \\
\text { entrants, some alliance activity, } \\
\text { somewhat dynamic and growing } \\
\text { markets }\end{array}$ & 173.0 & 11.7 & 2.7 & 64 & 35 & 15 \\
\hline $\begin{array}{l}\text { Automotive } \\
\text { transportation and } \\
\text { equipment, } \\
\text { 3711-3799 }\end{array}$ & $5(n=26)$ & $\begin{array}{c}\text { Frequent new product introduction } \\
\text { and incremental innovation, intense } \\
\text { competition, heavy alliance activity, } \\
\text { dynamic demand }\end{array}$ & 232.0 & 8.1 & 4.6 & 68 & 39 & 22 \\
\hline $\begin{array}{l}\text { Electronic and electric } \\
\text { equipment, } \\
\text { 3624-3647 }\end{array}$ & $6(n=48)$ & $\begin{array}{l}\text { Strong activity on multiple fronts: } \\
\text { radical innovation, technology, new } \\
\text { entrants, alliances, dynamic } \\
\text { markets and demand, intense } \\
\text { competition }\end{array}$ & 177.0 & 12.0 & 3.7 & 62 & 40 & 21 \\
\hline
\end{tabular}


coefficient, which compares the parsimonious second-order factor model with a measurement model that contains the three subconstructs, was at the acceptable level of .90 (Marsh and Hocevar 1985). As we expected, the three relationship-quality subconstructs loaded positively on overall relationship quality (i.e., trust: $\gamma_{1}=.94, \mathrm{t}=7.80, p<$ .001 ; commitment: $\gamma_{2}=.82, \mathrm{t}=8.49, p<.001$; stability: $\left.\gamma_{3}=.69, \mathrm{t}=6.15, p<.001\right)$. The $\chi^{2}$ for this model was $242.94(p<.01)$, with 88 degrees of freedom. The fit indexes were CFI $=.96, \mathrm{NFI}=.94$, and NNFI $=.96$. Reliability for the higher-order construct was .94 . We provide descriptive statistics for latent constructs in Table 2.

\section{Hypothesis Testing}

We used ordinary least squares regression to test our hypotheses. We used the product term between the concerned latent constructs to test the interaction effects; we used the square of the latent constructs to test the hypothesized nonlinear effects. Because product terms and the square terms can induce collinearity, we mean-centered the variables before we constructed the terms (Aiken and West 1996; Cronbach 1987). The reported results are based on mean-centered latent explanatory variables.

The results show that the independent variables explain significant variance in relationship portfolio effectiveness $\left(\mathrm{R}^{2}=.428, p<.01\right)$ and relationship quality $\left(\mathrm{R}^{2}=.121, p<\right.$ $.01)$. For the hypotheses, the results indicate support for $\mathrm{H}_{1}$; interactional knowledge stores enhance relationship portfolio effectiveness $(b=.320, p<.01)$ at an increasing rate $(b=.122, p<.01)$. We graph this nonlinear effect in Figure 2. We also find support for $\mathrm{H}_{2}$, which proposes that rich interactional knowledge stores enhance relationship quality $(\mathrm{b}=.343, p<.01)$.

The results do not indicate support for $\mathrm{H}_{3}$, which suggests that functional knowledge stores positively affect relationship portfolio effectiveness $\left(b=.049, p>.33\right.$ ). In $\mathrm{H}_{4}$, we expected that greater levels of functional knowledge stores would increase relationship quality at an increasing rate. Although the linear term for functional knowledge stores is not statistically significant $(\mathrm{b}=.029, p>.40)$, the nonlinear term is positive and significant $(b=.069, p<.05)$ for its effect on relationship quality, which provides support for $\mathrm{H}_{4}$. According to our data, as the level of functional knowledge stores increases, relationship quality is enhanced at an increasing rate (see Figure 2).

In $\mathrm{H}_{5}$ and $\mathrm{H}_{6}$, we expected that the influence of environmental knowledge stores on relationship portfolio effectiveness and individual relationship quality would be greater in turbulent environments. The results do not show support for $\mathrm{H}_{5}$. Neither the main effect of environmental knowledge store on relationship portfolio effectiveness $(b=-.039, p>$ .62) nor its interaction with environmental turbulence is statistically significant $(b=.013, p>.33)$. Likewise, the main effect of environmental knowledge stores on relationship quality is not statistically significant $(\mathrm{b}=-.050, p>.56)$. However, we find limited support for $\mathrm{H}_{6}$; the effect of envi-

FIGURE 2 Interpretation of Nonlinear Effects

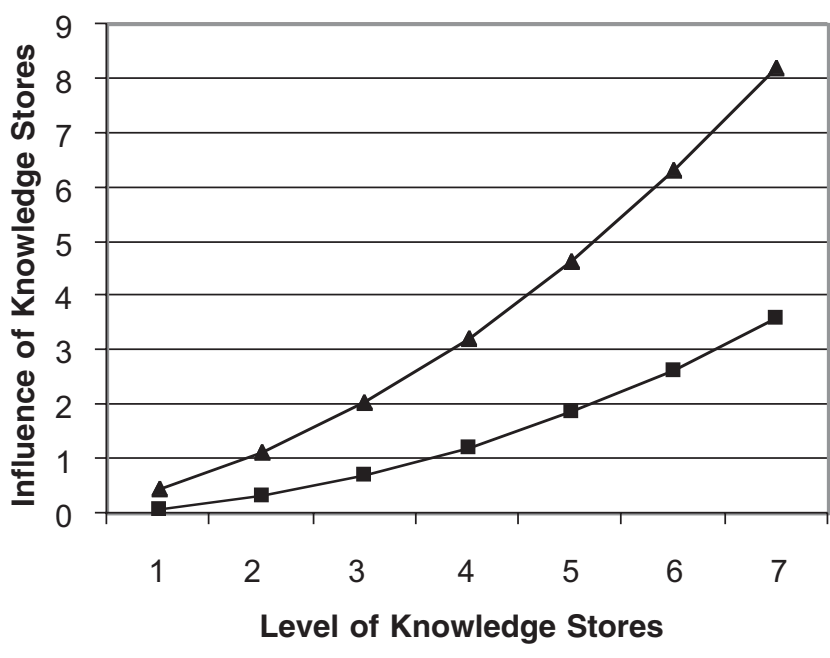

- Effect of functional knowledge
stores on relationship quality
$\rightarrow-$ Effect of interactional knowledge
stores on relationship portfolio
effectiveness

TABLE 2

Descriptive Statistics: Mean, Standard Deviations, and Correlations

\begin{tabular}{|c|c|c|c|c|c|c|c|}
\hline & 1 & 2 & 3 & 4 & 5 & 6 & 7 \\
\hline 1. Interactional knowledge stores & 1.00 & & & & & & \\
\hline 2. Functional knowledge stores & $.78^{\star \star}$ & 1.00 & & & & & \\
\hline 3. Environmental knowledge stores & $.66^{\star \star}$ & $.70^{\star *}$ & 1.00 & & & & \\
\hline 4. Sensemaking & $.57^{\star \star}$ & $.56^{\star \star}$ & $.47^{\star \star}$ & 1.00 & & & \\
\hline 5. Relationship quality & $.32^{\star \star}$ & $.23^{\star \star}$ & $.19^{\star}$ & $.22^{\star \star}$ & 1.00 & & \\
\hline 6. Relationship portfolio effectiveness & $.53^{\star \star}$ & $.47^{\star \star}$ & $.37^{\star *}$ & $.58^{* *}$ & $.28^{\star \star}$ & 1.00 & \\
\hline 7. Environmental turbulence & -.06 & -.01 & -.08 & .01 & -.02 & .03 & 1.00 \\
\hline Mean & 4.86 & 4.59 & 4.17 & 5.18 & 5.73 & 5.10 & 2.83 \\
\hline Standard deviation & 1.03 & 1.08 & 1.21 & 1.19 & 1.06 & .98 & 1.90 \\
\hline
\end{tabular}

${ }^{*} p<.05$.

${ }^{* \star} p<.01$. 
ronmental knowledge stores on relationship quality is moderated by environmental turbulence $(\mathrm{b}=.039, p<.10)$.

\section{Post Hoc Analysis of the Role of Turbulence}

Although preliminary hypotheses testing did not reveal a substantive pattern of moderation by environmental turbulence, powerful theoretical arguments indicate that there might be important effects that did not emerge in our analysis. Thus, we probed the moderating effects of environmental turbulence more comprehensively through a post hoc dummy-variable analysis. Specifically, for the environmental knowledge stores' impact on relationship portfolio effectiveness and relationship quality models, we replaced the turbulence index with six dummy variables, one for each level of environmental turbulence. Elimination of the constant term in the equation accommodated for the six dummy variables. Using the dummy variables and environmental knowledge stores, we created six product terms to reflect the influence of the knowledge store on the outcome for each of the six levels of turbulence (again, we deleted the main effect of environmental knowledge stores to accommodate the six interactions).

The middle section of Table 3 shows results for the dummy-variable turbulence model (although we included all original explanatory variables in the post hoc analysis, for parsimony and clarity, we report only the moderation results in Table 3). As is shown, environmental knowledge stores positively influence relationship portfolio effectiveness for Turbulence Level 3 but negatively for Level 4. For relationship quality, environmental knowledge stores' effects are positive for Turbulence Levels 3-5. To further examine differences in the influence of the environmental knowledge stores across environmental conditions, we used Wald tests to compare the coefficients reported in the middle of Table 3 (for each knowledge store, there are 15 such comparisons, i.e., ${ }^{6} \mathrm{C}_{2}=15$ ). The comparisons shown in the lower section of Table 3 indicate that in our data, the influence of environmental knowledge stores on relationship portfolio effectiveness and relationship quality varies from one level of turbulence to another. For example, the effects of the environmental knowledge store on relationship portfolio effectiveness differ significantly between Turbulence Level 3 and the other five levels (Levels 3 and 2: b $=.809$, $p<.01$; Levels 3 and $1: \mathrm{b}=.796, p<.01$; Levels 4 and 3 : $\mathrm{b}=-1.053, p<.01 ;$ Levels 5 and $3: \mathrm{b}=-.861, p<.05$; and Levels 6 and $3: \mathrm{b}=-.733, p<.01)$. Consistent with $\mathrm{H}_{5}$ and $\mathrm{H}_{6}$, the post hoc analyses reveal that environmental knowledge stores influence IR outcomes differently in various environmental conditions.

\section{The Role of Sensemaking in IR Knowledge Store Development}

Although we did not formally specify hypotheses regarding the role of sensemaking, we treat it as a covariate and test its effect on relationship portfolio effectiveness because, at a broader level, sensemaking can facilitate how IRs work together as a group. Furthermore, sensemaking can determine how various relationships complement one another, and how each works in conjunction with others (e.g., Bensaou and Venkatraman 1995). The results show that sense- making has a positive, direct influence on relationship portfolio effectiveness $(b=.386, p<.01) .{ }^{1}$

With regard to the role of sensemaking in knowledge store development, the correlations reported in Table 2 show a strong pattern of association between sensemaking and the IR knowledge stores. The coefficients of .57 ( $p<$ $.01), .56(p<.01)$, and $.47(p<.01)$ for interactional, functional, and environmental knowledge stores, respectively, provide preliminary evidence of a strong role for sensemaking in knowledge development. To explore the question of environmental moderation in knowledge store development, we performed the same post hoc analysis as we did with the outcomes of knowledge stores. As the results in Table 4 show, 17 of the 18 coefficients for sensemaking are positive and statistically significant $(p<.05)$, which indicates that in most environmental conditions, sensemaking positively influences IR knowledge stores. The Wald test results in Table 4 show that for interactional and environmental knowledge stores, the influence of sensemaking differs across turbulence. However, this difference is not a simple linear difference that can be captured by one interaction term. For example, in the case of interactional knowledge stores, sensemaking has a greater impact for Turbulence Level 6 than for Level $2(b=.272, p<.05)$ and Level $4(b=$ $.276, p<.01)$. However, the effect of sensemaking on interactional knowledge stores is lower for Turbulence Level 6 than for Level $3(\mathrm{~b}=-.209, p<.05)$. Nonetheless, our data indicate that sensemaking is important in developing knowledge stores, and its effects vary depending on the level of environmental turbulence.

\section{Discussion}

We drew on the absorptive capacity perspective to extend our understanding of relational capability. We advanced the notion that relational capability derives from the development, and particularly the leveraging, of knowledge stores specific to the domain of IR making and management. An important issue in our research involves the differential effects of the three knowledge subdomains (relational, functional, and environmental) that underpin interfirm relational capability. As we expected, our results imply that the three relational knowledge stores indeed generate different outcomes in individual IRs and in terms of a firm's IR portfolio.

Interactional knowledge stores seem to be an important factor in terms of both the magnitude and the consistency of their effects. The knowledge stores strongly influence individual IR quality and have broader-based implications for the IR portfolio. The influence on portfolio effectiveness

\footnotetext{
${ }^{1}$ An interesting question that arises is whether the three knowledge stores mediate the influence of sensemaking on relationship portfolio effectiveness. To test this, we estimated a model in which sensemaking affected relationship portfolio effectiveness in the absence of the influence of the knowledge stores $(b=.513, p<$ $.01)$. Because this coefficient is substantially greater than the coefficient estimated in the presence of the knowledge stores (i.e., $b=$ .386, $p<.01)$ in absolute magnitude, we have evidence for partial mediation (Baron and Kenny 1986).
} 
TABLE 3

Ordinary Least Squares Results

\begin{tabular}{|c|c|c|c|c|}
\hline \multicolumn{3}{|c|}{$\begin{array}{c}\text { Relationship Portfolio } \\
\text { Effectiveness }\end{array}$} & \multicolumn{2}{|c|}{ Relationship Quality } \\
\hline Explanatory Variable & $\begin{array}{l}\text { Jnstandardized } \\
\text { Parameter } \\
\text { Estimate }\end{array}$ & $\begin{array}{c}\text { Standard } \\
\text { Error }\end{array}$ & $\begin{array}{l}\text { Unstandardized } \\
\text { Parameter } \\
\text { Estimate }\end{array}$ & $\begin{array}{l}\text { Standard } \\
\text { Error }\end{array}$ \\
\hline Interactional knowledge stores & $.320^{\star \star \star}$ & .109 & $.343^{* * *}$ & .111 \\
\hline Functional knowledge stores & .049 & .115 & .029 & .121 \\
\hline Environmental knowledge stores & -.039 & .079 & -.050 & .088 \\
\hline Environmental turbulence & .028 & .031 & .006 & .034 \\
\hline Sensemaking & $.386^{\star \star \star}$ & .079 & - & - \\
\hline Interactional knowledge stores 2 & $.122^{\star \star \star}$ & .037 & - & - \\
\hline Functional knowledge stores? & - & - & $.069^{\star *}$ & .034 \\
\hline \multirow{2}{*}{ Environmental knowledge stores $\times$ turbulence } & .013 & .030 & $.039^{*}$ & .029 \\
\hline & $\mathrm{R}^{2}=$ & & \multicolumn{2}{|c|}{$\mathrm{R}^{2}=.121$} \\
\hline
\end{tabular}

Environmental Knowledge Stores at Environmental Turbulence Levelsa

\begin{tabular}{lcccc}
\hline Lowest (1) & -.059 & .117 & -.096 & .123 \\
Somewhat low (2) & -.072 & .094 & -.168 & .134 \\
Moderate (3) & $.737^{\star \star *}$ & .267 & $.348^{\star}$ & $.521^{\star * *}$ \\
Fair (4) & $-.316^{\star *}$ & .175 & $.684^{\star * *}$ & .155 \\
Somewhat high (5) & -.124 & .319 &. .018 & .155 \\
Highest (6) & .005 & .130 & .113
\end{tabular}

Wald Tests Comparing Moderation of Environmental Turbulence on Outcomes ${ }^{b}$

\begin{tabular}{|c|c|c|c|c|}
\hline $\begin{array}{l}(6)-(5) \\
(6)-(4) \\
(6)-(3) \\
(6)-(2) \\
(6)-(1) \\
(5)-(4) \\
(5)-(3) \\
(5)-(2) \\
(5)-(1) \\
(4)-(3) \\
(4)-(2) \\
(4)-(1) \\
(3)-(2) \\
(3)-(1) \\
(2)-(1)\end{array}$ & $\begin{array}{l}.129 \\
.320^{\star} \\
-.733^{\star \star \star} \\
.076 \\
.063 \\
.192 \\
-.861^{\star \star} \\
-.053 \\
-.066 \\
-1.053^{\star \star \star} \\
-.244 \\
-.257 \\
.809^{\star \star \star} \\
.796^{\star \star \star} \\
-.013\end{array}$ & $\begin{array}{l}.336 \\
.219 \\
.291 \\
.144 \\
.156 \\
.365 \\
.405 \\
.324 \\
.330 \\
.313 \\
.191 \\
.201 \\
.263 \\
.270 \\
.118\end{array}$ & $\begin{array}{l}-.702^{\star \star \star} \\
-.539^{\star \star \star} \\
-.366^{\star} \\
.151 \\
.078 \\
.162 \\
.336^{\star} \\
.852^{\star \star \star} \\
.780^{\star \star \star} \\
.173 \\
.690^{\star \star \star} \\
.617^{\star \star \star} \\
.516^{\star \star} \\
.444^{\star \star} \\
-.073\end{array}$ & $\begin{array}{l}.174 \\
.192 \\
.234 \\
.151 \\
.145 \\
.217 \\
.243 \\
.186 \\
.176 \\
.252 \\
.199 \\
.191 \\
.232 \\
.215 \\
.153\end{array}$ \\
\hline \multicolumn{5}{|c|}{ 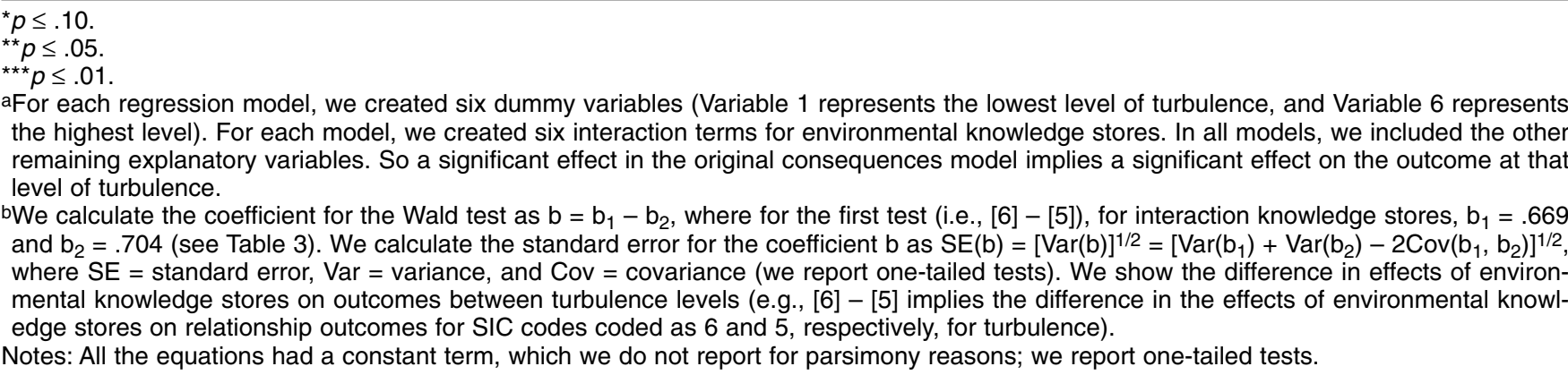 } \\
\hline
\end{tabular}

not only is strong but also gains momentum through positive feedback effects. Evidently, investment in this particular knowledge store generates returns at an increasing rate for the firm. Our results indicate that the benefits of this knowledge domain are not confined to one or a few limited relationships. Rather, when this knowledge domain is developed, it is transferable and generalizable and, more impor- tant, can be parlayed repeatedly into positive outcomes for the firm.

For functional knowledge stores, we expected that the benefits realized in an individual IR would multiply at an increasing rate. In general, the data indicate that with respect to the individual relationship, investment in functional knowledge stores yields large payoffs, and these pay- 
TABLE 4

Effects of Sensemaking on IR Knowledge Stores at Various Levels of Environmental Turbulence

\begin{tabular}{|c|c|c|c|}
\hline $\begin{array}{l}\text { Levels of } \\
\text { Turbulencea }\end{array}$ & $\begin{array}{l}\text { Interactional } \\
\text { Knowledge } \\
\text { Stores }\end{array}$ & $\begin{array}{c}\text { Functional } \\
\text { Knowledge } \\
\text { Stores }\end{array}$ & $\begin{array}{c}\text { Environmental } \\
\text { Knowledge } \\
\text { Stores }\end{array}$ \\
\hline Lowest (1) & $.556^{\star \star \star}$ & $.664^{\star \star \star}$ & $.473^{\star \star \star}$ \\
\hline Somewhat low (2) & $.379^{\star \star \star}$ & $.454^{\star \star \star}$ & $.768^{\star \star \star}$ \\
\hline Moderate (3) & $.878^{\star \star}$ & $.939^{\star \star}$ & $1.047^{\star \star \star}$ \\
\hline Fair (4) & $.393^{\star \star \star}$ & $.571^{\star \star *}$ & $-.218^{\star \star}$ \\
\hline Somewhat high (5) & $.704^{\star \star \star}$ & $.686^{\star \star \star}$ & $.819^{\star \star \star}$ \\
\hline Highest (6) & $.669^{\star \star \star}$ & $.455^{\star \star}$ & $.617^{\star \star \star}$ \\
\hline
\end{tabular}

Wald Tests Comparing Moderation of Environmental Turbulence on Outcomes $b$

\begin{tabular}{|c|c|c|c|}
\hline$(6)-(5)$ & -.035 & -.232 & -.202 \\
\hline (6) $-(4)$ & $.276^{\star \star \star}$ & -.116 & $.843^{\star \star \star}$ \\
\hline$(6)-(3)$ & $-.209^{\star \star}$ & -.484 & $-.431^{\star \star \star}$ \\
\hline$(6)-(2)$ & $.272^{\star \star}$ & .001 & .151 \\
\hline$(6)-(1)$ & .113 & -.209 & .144 \\
\hline$(5)-(4)$ & $.311^{* \star}$ & .115 & $1.037^{\star \star *}$ \\
\hline$(5)-(3)$ & -.174 & -.253 & $-.228^{*}$ \\
\hline$(5)-(2)$ & $.307^{\star}$ & .233 & $.353^{\star *}$ \\
\hline$(5)-(1)$ & .148 & .022 & $.347^{\star \star}$ \\
\hline$(4)-(3)$ & $-.485^{\star \star \star}$ & -.368 & $-1.265^{\star * *}$ \\
\hline$(4)-(2)$ & -.004 & .117 & $-.683^{\star \star \star}$ \\
\hline$(4)-(1)$ & -.163 & -.093 & $-.690^{\star \star \star}$ \\
\hline$(3)-(2)$ & $.481^{\star \star \star}$ & .485 & $.581^{\star \star *}$ \\
\hline$(3)-(1)$ & $.321^{\star \star \star}$ & .275 & $.574^{\star \star \star}$ \\
\hline$(2)-(1)$ & -.159 & $-.210^{\star}$ & -.007 \\
\hline
\end{tabular}

${ }^{\star} p \leq .10$.

${ }^{* *} p \leq .05$.

${ }^{* * *} p \leq .01$.

aFor each regression model, we created six dummy variables (Variable 1 represents the lowest level of turbulence, and Variable 6 represents the highest level). For each model, we created six interaction terms for sensemaking. Interactional knowledge stores $\mathrm{R}^{2}=.39$, functional knowledge stores $\mathrm{R}^{2}=.36$, and environmental knowledge stores $\mathrm{R}^{2}=.29$.

bWe calculate the coefficient for the Wald test $a s b=b_{1}-b_{2}$, where for the first test (i.e., [6] $-[5]$ ), for interaction knowledge stores, $b_{1}=.669$ and $b_{2}=.704$ (see Table 3). We calculate the standard error for the coefficient $b$ as $\operatorname{SE}(b)=[\operatorname{Var}(b)]^{1 / 2}=\left[\operatorname{Var}\left(b_{1}\right)+\operatorname{Var}\left(b_{2}\right)-2 C o v\left(b_{1}, b_{2}\right)\right]^{1 / 2}$, where SE = standard error, Var = variance, and Cov = covariance (we report one-tailed tests). We show the difference in effects of sensemaking on the three knowledge stores between turbulence levels (e.g., [6] - [5] implies the difference in the effects of sensemaking on each knowledge store for SIC codes coded as 6 and 5, respectively, for turbulence.

offs gain momentum and amplify. We also believed that whereas functional knowledge would have some broaderbased application over a firm's portfolio, it would be less generalizable and transferable. Rather than leveraging the functional knowledge stores readily from one IR to another, only limited pockets of knowledge would transfer across IRs. According to our data, functional knowledge does not have significant portfoliowide benefits. This implies that learning about, for example, JIT or other inventory management systems in a relationship may not necessarily result in skills or subroutines that the firm can leverage to enhance the effectiveness of its relationships with other partners.

Another focus of our research involves the moderating effects of environmental turbulence on the use of the environmental knowledge stores. Although environmental knowledge does not affect outcomes in all conditions, post hoc investigations show a pattern of moderation by environmental turbulence. In industries characterized by moderate levels of turbulence, environmental knowledge seems to enable portfolio effectiveness greatly. It facilitates adjustments and reorientations in the portfolio to accommodate for some reasonable level of change in the environment. However, at the highest level of turbulence, this knowledge may not be sufficient to cope with changes. With respect to relationship quality, the effects of environmental knowledge stores are similar, though they come into play at somewhat higher levels of turbulence. The magnitude of the differences in effects of environmental knowledge stores at various levels of industry turbulence suggests that marketing scientists must do more to understand how the management of IRs should differ in various environmental conditions. Given our treatment of the environment at an industry level, examination of turbulence in terms of industry conditions may be useful.

For the role of sensemaking, evidence indicates that it is strongly associated with the development of knowledge stores. Furthermore, it seems that sensemaking enhances knowledge stores regardless of environmental conditions. However, we must temper our conclusions somewhat with regard to two of the knowledge stores. We have found what appears to be a nonlinear moderation effect between sensemaking and environmental turbulence for interactional and environmental knowledge stores (i.e., the moderation occurs only at certain levels of turbulence and in certain forms, as opposed to a monotonic bilinear moderation). Although implications of this pattern of moderation are not 
entirely clear, in general, sensemaking seems to be most productive at medium to high levels of turbulence.

\section{Contributions and Managerial Implications}

Scholars note that knowledge is crucial on several fronts, yet there is a scarcity of empirical research that investigates the role of knowledge, especially in IRs. We advance the emergent literature on relational capabilities by showing that domain-specific IR knowledge stores play a crucial and complex role in developing and managing relationships. Related to this, we advance the buyer-seller relationship literature by offering an expanded perspective on IR outcomes. We augment traditional treatments of relationship quality (e.g., Hibbard, Kumar, and Stern 2001; Jap 1999) by including a relationship portfolio perspective in accordance with recent assertions that close, partner-type relationships may not be universally desirable (e.g., Buvik and John 2000).

In addition to the theoretical contributions, our research has several implications for managers. Several leading companies (e.g., BP, Ford, Coca-Cola, General Electric, Monsanto, IBM) have made knowledge management a top priority, on the basis of the premise that knowledge is crucial for competing in today's economy (Hackett 2000). On a broad level, our study validates the action of these companies and underscores the role of knowledge as a strategic resource.

Furthermore, our study has implications for a firm's relationship-marketing strategy. Examples of companies using relational knowledge stores are well documented in the customer relationship management literature. In addition, firms can leverage their functional knowledge stores to enhance relationship quality in several ways. For example, Intel has created personalized Web sites for 10,000 buyers in 400 companies to order its microprocessors, check their order status, and collaborate with engineers. Although the personalized Web sites shorten the order-fulfillment cycles to some extent, their real value is in building and strengthening relationships with partners. Cisco Systems' knowledge-exchange system connects its employees with its customers and suppliers. By sharing information about sensitive issues such as sales forecasts, Cisco has been able to build trust with its channel partners (Knowledge Management 2001). Dell's Virtual Integration System enables it to share information and knowledge freely with its external suppliers on a real-time basis (Magretta 1998). Although the information sharing permits tighter coordination of the supply chain, it also helps develop higher-quality relationships.

However, the results indicate that functional knowledge does not enhance overall relationship portfolio effectiveness. This has implications for companies such as Toyota that have created a knowledge-sharing network with suppliers (Ahmadjian and Lincoln 2001; Dyer and Nobeoka 2000). According to our data, the leveraging of functional knowledge across a portfolio of IRs may not be productive; functional knowledge does not seem to transfer readily or to generalize across a range of relationships. To capitalize on this knowledge, firms may be better off developing and leveraging functional knowledge stores that focus on individual relationships.
Addressing an uncertain environment is an issue of importance to most managers. Our research suggests that by developing knowledge bases about trends and changes in the external environment, firms are in a better position to manage relationships. Consider an example from the food industry: Manufacturers of food and consumer packaged goods own vast amounts of information on market trends, demographics, and consumer behavior. Supermarkets have large databases of information on individual and household purchasing activity. Seven manufacturers (Anheuser-Busch, Coca-Cola, Kraft Foods, Pillsbury, Procter \& Gamble, Nabisco, and Warner-Lambert) and one supermarket chain (Wegmans Food Markets) combined the two sets of information to better manage their relationships with customers (Goldberg 2000). However, the usefulness and applicability of environmental knowledge stores is a function of the turbulence level in the industry environment. Apparently, such knowledge stores can be leveraged most effectively in moderately turbulent industries.

Another issue of importance for managers intent on capabilities development is the content of knowledge: What type of knowledge results in strong capabilities and superior performance? Our research implies that there is no standard mix of knowledge. Rather, the content domain of knowledge depends on the specific capability involved. Firms should focus on knowledge that underpins capabilities in specific strategically crucial functional areas (e.g., IRs). Even further, within these functional areas, the firm can and should build various relevant subdomains such that strong capabilities emerge. Our research shows that the various knowledge subdomains have differential and sometimes nonlinear impacts, which implies that, as with other resources, firms must understand how to combine and leverage the subdomains for optimal outcomes.

Our research suggests that the prudent manager should devote efforts and resources to sensemaking because it is critical in capabilities development. Managerial focus on sensemaking may be even more vital than our data indicate because it can be broken down into specific actions and activities that can be trained and rewarded in the firm. The literature is replete with admonitions that firms must be learning organizations and must "learn how to learn." With a focus on sensemaking, managers can isolate activities and skills necessary to the perpetual adjustment and reframing of events and cues. Managers can be trained in the search for critical questions that need to be asked, even as they search for answers to the questions. Personnel assessments and reviews could directly address sensemaking activities, linking them directly to performance evaluations and financial rewards for relevant managers and thereby reinforcing training efforts.

\section{Limitations and Further Research}

The results of this study must be viewed in conjunction with its limitations. A measurement concern involves the scope and domain of our formative measures for the IR knowledge stores. The validity of formative measures hinges on extensive tapping of the construct domain, if not exhaustion of it. Although our measures are well grounded in theory and fieldwork with managers, they are new. 
Therefore, construct domains need to be further verified and established. In addition, our results may be strengthened by the inclusion of additional informants for each firm or perhaps by the development of objective measures. Although we took precautions in questionnaire development and pretesting, and the results do not seem to indicate it, common methods variance can be problematic in singleinformant survey data.

Our research is the first we know of that has empirically verified the existence of environmental moderation in learning. Furthermore, this moderation is quite complex in form and warrants further investigation before any detailed conclusions can be drawn. Our measure for environmental variance has the important advantage of being derived from objective secondary data. However, it is ordinal in nature and is based on assessments of industry conditions. Given that reasonably strong findings emerged with this objective but somewhat limited environmental turbulence measure, it is critical to managers and researchers that this issue be extensively addressed in further research. A multifaceted measure of environmental turbulence may reveal more about this complex and subtle phenomenon.

Although this study offers important groundwork for understanding IR knowledge stores, more research is needed on how the knowledge is developed. Related to this, tracking the evolution of sensemaking skills and their implications for knowledge creation would be useful. Another issue in this research and all capabilities and learning research is the connection to firm-level performance outcomes. The firm is necessarily driven by the need to "take it to the bank." Performance implications of learning and capabilities have strong and compelling theoretical grounding, but how and when do they play out in firm performance? These issues are difficult ones, but it is critical to address them in the IR context.

\section{Appendix Measures}

\section{Knowledge Stores (New Scale; Formative)}

(Scale items anchored by 1 = "very little knowledge" and 7 = "lots of knowledge")

\section{Interactional}

1. Negotiating with suppliers

2. Planning and management of partnering activities

3. Initiating and implementing cooperative programs with suppliers

4. Using computers to network and communicate with suppliers

5. Managing conflict with suppliers

\section{Functional}

1. Cost-reduction strategies involving suppliers

2. Working with supplier to develop products

3. Working with suppliers to reduce delivery times

4. Working with suppliers on quality management

5. Integrating suppliers into the firm's JIT system

6. Enhancing suppliers' production capabilities and capacities

\section{Environmental}

1. Laws and regulations relevant to supplier relationships

2. Market conditions affecting buying

3. Labor conditions in supplier firms

4. Competitors' purchasing behaviors

\section{Relationship Quality (Conceptualized as a Higher- Order Construct That Consists of ...)}

Trust (scale adapted from Doney and Cannon 1997)

(Construct reliability $=.95$; AVE $=.75$; range of loadings .85-.91; scale items anchored by $1=$ "strongly disagree" and 7 = "strongly agree")

1. This supplier keeps promises made to our firm.

2. This supplier is always frank and truthful with us.

3. We believe the information this supplier provides us.

4. This supplier is genuinely concerned that our business succeeds.

5. When making decisions, this supplier considers our welfare as well as their own.

6. This supplier is trustworthy.

Commitment (scale adapted from Anderson and Weitz 1992)

(Construct reliability $=.94 ; \mathrm{AVE}=.77$; range of loadings .78-.95; scale items anchored by $1=$ "strongly disagree" and 7 = "strongly agree")

1. We have a strong sense of loyalty to this supplier.

2. We expect this supplier to be working with us a long time.

3 . We are willing to make long-term investments to help this supplier.

4. We are really committed to developing a working relationship with this supplier.

5. We see this relationship as a long-term alliance.

Relationship stability (new scale)

(Construct reliability $=.91$; AVE $=.73$; range of loadings .74-.95; responses ranged from 1 to 7 on bipolar adjectives)

1. Stable/unstable (reverse coded)

2. Long-term/short-term (reverse coded)

3. Insecure/secure

4. Unsteady/steady

\section{IR Portfolio Effectiveness (New Scale)}

(Construct reliability $=.91 ; \mathrm{AVE}=.72$; range of loadings $.80-.90$; scale items anchored by $1=$ "strongly disagree" and 7 = "strongly agree")

1. For the most part, our supplier relationships are very effective.

2. Across the board, our supplier relationships operate well for us.

3. Our supplier relationships do everything we need them to do and more.

4. In general, we find our supplier relationships to be very productive and efficient. 


\section{Sensemaking (New Scale)}

(Construct reliability $=.91$; AVE $=.73$; range of loadings .76-.93; scale items anchored by $1=$ "strongly disagree" and 7 = "strongly agree")

In our supplier relationships ...

1. If something seems to be going wrong, we try hard to figure out why.
2. We quickly try to identify our mistakes so that they are not repeated.

3. If a program is successful, we try to understand what makes it work well.

4. If we see a mistake has been made, we retrace our actions to understand what happened.

5. We constantly assess and analyze the effects of our decisions so that we know what adjustments to make.

\section{REFERENCES}

Achrol, Ravi S. (1991), "Evolution of the Marketing Organization: New Forms for Turbulent Environments," Journal of Marketing, 55 (July), 77-93.

- Torger Reve, and Louis W. Stern (1983), "The Environment of Marketing Channel Dyads: A Framework for Comparative Analysis," Journal of Marketing, 47 (Fall), 55-67.

and Louis W. Stern (1988), "Environmental Determinants of Decision-Making Uncertainty in Marketing Channels," Journal of Marketing Research, 25 (February), 36-50.

Ahmadjian, Christina L. and James R. Lincoln (2001), "Keiretsu, Governance, and Learning: Case Studies in Change from the Japanese Automotive Industry," Organization Science, 12 (November-December), 683-701.

Aiken, Leona S. and Stephen G. West (1996), Multiple Regression: Testing and Interpreting Interactions. Thousand Oaks, CA: Sage Publications.

Anderson, Erin and Barton Weitz (1992), "The Use of Pledges to Build and Sustain Commitment in Distribution Channels," Journal of Marketing Research, 29 (February), 18-34.

Anderson, James C. and David W. Gerbing (1988), "Structural Equations Modeling in Practice: A Review and Recommended Two Step Approach," Psychological Bulletin, 103 (May), 411-23.

Armstrong, J. Scott and Terry S. Overton (1977), "Estimating Nonresponse Bias in Mail Surveys," Journal of Marketing Research, 14 (August), 396-402.

Arthur, W.B. (1994), Increasing Returns and Path Dependence in the Economy. Ann Arbor: University of Michigan Press.

Baker, William E. and James M. Sinkula (1999), "The Synergistic Effect of Market Orientation and Learning Orientation on Organizational Performance," Journal of the Academy of Marketing Science, 27 (Fall), 411-27.

Baron, Reuben M. and David A. Kenny (1986), "The ModeratorMediator Variable Distinction in Social Psychology Research: Conceptual, Strategic, and Statistical Considerations," Journal of Personality and Social Psychology, 51 (December), 1173-82.

Bensaou, M. and N. Venkatraman (1995), "Configurations of Interorganizational Relationships: A Comparison Between U.S. and Japanese Automakers," Management Science, 41 (September), 1471-92.

Buvik, Arnt and George John (2000), "When Does Vertical Coordination Improve Industrial Purchasing Relationships?" Journal of Marketing, 64 (October), 52-64.

Campbell, Donald T. (1955), "The Informant in Quantitative Research," American Journal of Sociology, 60 (January), 339-42.

Cannon, Joseph P. and William D. Perreault Jr. (1999), "Buyer-Seller Relationships in Business Markets," Journal of Marketing Research, 36 (November), 439-60.

Celly, Kirti Sawhney, Robert E. Spekman, and John W. Kamauff (1999), "Technological Uncertainty, Buyer Preferences, and Supplier Assurances: An Examination of Pacific Rim Purchasing Arrangements," Journal of International Business Studies, 30 (Second Quarter), 297-316.
Cohen, Wesley M. and Daniel A. Levinthal (1990), "Absorptive Capacity: A New Perspective on Learning and Innovation," Administrative Science Quarterly, 35 (March), 128-52.

Collis, David J. (1994), "Research Note: How Valuable Are Organizational Capabilities?" Strategic Management Journal, 15 (Winter Special Issue), 153-52.

Cronbach, Lee J. (1987), "Statistical Tests for Moderator Variables: Flaws in Analysis Recently Proposed," Psychological Bulletin, 102 (November), 414-17.

Crosby, Lawrence A., Kenneth R. Evans, and D. Cowles (1990), "Relationship Quality in Services Selling: An Interpersonal Influence Perspective," Journal of Marketing, 54 (July), 68-81.

Day, George S. (1994), "The Capabilities of Market-Driven Organizations," Journal of Marketing, 58 (October), 37-52.

(2000), "Capabilities for Forging Customer Relationships," Working Paper No. 00-118, Marketing Science Institute.

Diamantopoulos, Adamantios and Heidi M. Winklhofer (2001), "Index Construction with Formative Indicators: An Alternative to Scale Development," Journal of Marketing Research, 38 (May), 269-77.

Dickson, Peter R., Paul W. Farris, and Willem J.M.I. Verbeke (2001), "Dynamic Strategic Thinking," Journal of the Academy of Marketing Science, 29 (Summer), 216-37.

Doney, Patricia M. and Joseph P. Cannon (1997), "An Examination of the Nature of Trust in Buyer-Seller Relationships," Journal of Marketing, 61 (April), 35-51.

Douglas, Thomas J. and William Q. Judge Jr. (2001), “Total Quality Management Implementation and Competitive Advantage: The Role of Structural Control and Exploration," Academy of Management Journal, 44 (February), 158-69.

Dwyer, F. Robert and M. Ann Welsh (1985), "Environmental Relationships of the Internal Political Economy of Marketing Channels," Journal of Marketing Research, 22 (November), 397-414.

Dyer, Jeffrey H. and Kentaro Nobeoka (2000), "Creating and Managing High-Performance Knowledge-Sharing Network: The Toyota Case," Strategic Management Journal, 21 (March), 345-67.

and Harbir Singh (1998), "The Relational View: Cooperative Strategy and Sources of Interorganizational Competitive Advantage," Academy of Management Review, 23 (October), 660-79.

Edwards, Jeffrey R. and Richard P. Bagozzi (2000), "On the Nature and Direction of Relationships Between Constructs and Measures," Psychological Methods, 5 (2), 155-74.

Eisenhardt, Kathleen M. and Jeffrey A. Martin (2000), "Dynamic Capabilities: What Are They?" Strategic Management Journal, 21 (October-November), 1105-1121.

Flynn, Barbara B., Sadao Sakakibara, and Roger G. Schroeder (1995), "Relationship Between JIT and TQM: Practices and Performance," Academy of Management Journal, 38 (October), 1325-60.

Ford, David and R. McDowell (1999), "Managing Business Relationships by Analyzing the Effects and Value of Different 
Actions," Industrial Marketing Management, 28 (September), 429-42.

Fornell, Claes and David F. Larcker (1981), "Evaluating Structural Equation Models with Unobservable Variables and Measurement Error," Journal of Marketing Research, 28 (February), 39-50.

Frazier, Gary L. (1999), "Organizing and Managing Channels of Distribution," Journal of the Academy of Marketing Science, 27 (Spring), 226-40.

$\longrightarrow$, Robert E. Spekman, and Charles R. O’Neal (1988), “JustIn-Time Exchange Relationships in Industrial Markets," Journal of Marketing, 52 (October), 52-67.

Ganesan, Shankar (1993), "Negotiation Strategies and the Nature of Channel Relationships," Journal of Marketing Research, 30 (May), 183-204.

_ _ (1994), "Determinants of Long-Term Orientation in Buyer-Seller Relationships," Journal of Marketing, 56 (April), $1-19$.

Glazer, Rashi (1991), "Marketing in an Information-Intensive Environment: Strategic Implications of Knowledge as an Asset," Journal of Marketing, 55 (October), 1-19.

Goldberg, Eddy (2000), "Consumer Knowledge Creates Better Trading Relationships," Food Logistics, 34 (September), 52-54.

Grewal, Rajdeep and Ravi Dharwadkar (2002), "The Role of the Institutional Environment in Marketing Channels," Journal of Marketing, 66 (July), 82-97.

Hackett, Brian (2000), "Beyond Knowledge Management: New Ways to Work and Learn," Research Report 1262-00-RR, The Conference Board.

Heide, Jan B. and George John (1990), "Alliances in Industrial Purchasing: The Determinants of Joint Action in BuyerSupplier Relationships," Journal of Marketing Research, 27 (February), 24-36.

Hibbard, Jonathan D., Nirmalya Kumar, and Louis W. Stern (2001), "Examining the Impact of Destructive Acts in Marketing Channel Relationships," Journal of Marketing Research, 38 (February), 45-61.

Howell, Roy (1987), "Covariance Structure Modeling and Measurement Issues: A Note on 'Interrelations Among a Channel Entity's Power Sources,"' Journal of Marketing Research, 24 (February), 119-26.

Hult, G. Tomas M. and O.C. Ferrell (1997), "Global Organizational Learning Capacity in Purchasing: Construct and Measurement," Journal of Business Research, 40 (October), 97-111.

Hurley, Robert F. and G. Tomas M. Hult (1998), "Innovation, Market Orientation, and Organizational Learning: An Integration and Empirical Examination," Journal of Marketing, 62 (July), 42-54.

Jap, Sandy (1999), "Pie-Expansion Efforts: Collaboration Processes in Buyer-Seller Relationships," Journal of Marketing Research, 36 (November), 461-75.

(2001), "'Pie Sharing' in Complex Collaboration Contexts," Journal of Marketing Research, 38 (February), 86-99.

Johnson, Jean L. (1999), "Strategic Integration in Industrial Distribution Channels: Managing the Interfirm Relationship as a Strategic Asset," Journal of the Academy of Marketing Science, 27 (Winter), 4-18.

Keister, Lisa A. (1999), "Where Do Strong Ties Come From? A Dyad Analysis of the Strength of Interfirm Exchange Relations During China's Economic Transition," International Journal of Organizational Analysis, 7 (January), 5-24.

Klein, Saul, Gary L. Frazier, and Victor J. Roth (1990), "A Transaction Cost Analysis Model of Channel Integration in International Markets," Journal of Marketing Research, 27 (May), 196-209.

Knowledge Management (2001), “Don’t Build Your E-Business Without KM," (March), 74-75.
Lane, Peter J., Balaji Koka, and Seemantini Pathak (2002), "A Thematic Analysis and Critical Assessment of Absorptive Capacity Research," in Academy of Management Proceedings, Dennis Nagao, ed. Denver: Academy of Management Association, M1-M6.

___ and Michael Lubatkin (1998), "Relative Absorptive Capacity and Interorganizational Learning," Strategic Management Journal, 19 (May), 461-77.

_ Jane E. Salk, and Marjorie A. Lyles (2001), “Absorptive Capacity, Learning, and Performance in International Joint Ventures," Strategic Management Journal, 22 (December), 1139-61.

Lehmann, Donald R. and Katherine E. Jocz, eds. (1997), Reflections on the Future of Marketing. Cambridge, MA: Marketing Science Institute.

Leonard-Barton, Dorothy (1992), "Core Capabilities and Core Rigidities: A Paradox in Managing New Product Development," Strategic Management Journal, 13 (March), 111-25.

Li, Tiger and Roger J. Calantone (1998), "The Impact of Market Knowledge Competence on New Product Advantage: Conceptualization and Empirical Examination," Journal of Marketing, 62 (October), 13-29.

Lukas, Bryan A., G. Tomas M. Hult, and O.C. Ferrell (1996), "A Theoretical Perspective of the Antecedents and Consequences of Organizational Learning in Marketing Channels," Journal of Business Research, 36 (July), 233-44.

Madhavan, Ravindranath and Rajiv Grover (1998), "From Embedded Knowledge to Embodied Knowledge: New Product Development as Knowledge Management," Journal of Marketing, 62 (October), 1-12.

Magretta, Joan (1998), "The Power of Integration: An Interview with Dell Computer's Michael Dell," Harvard Business Review, 76 (March-April), 73-84.

Marsh, Herbert W. and Dennis Hocevar (1985), "Application of Confirmatory Factor Analysis to the Study of Self-Concept: First- and Higher-Order Factor Models and Their Invariance Across Groups," Psychological Bulletin, 97 (November), $562-82$.

Mintzberg, Henry and James A. Waters (1985), "Of Strategies, Deliberate and Emergent," Strategic Management Journal, 6 (July-September), 257-72.

Mohr, Jakki J., Robert J. Fisher, and John R. Nevin (1996), "Collaborative Communication in Interfirm Relationships: Moderating Effects of Integration and Control," Journal of Marketing, 60 (July), 103-115.

and Sanjit Sengupta (2002), "Managing the Paradox of Inter-firm Learning: The Role of Governance Mechanisms," Journal of Business and Industrial Marketing, 17 (4), 282-301.

Moorman, Christine and Anne S. Miner (1997), "The Impact of Organizational Memory on New Product Performance and Creativity," Journal of Marketing Research, 34 (February), 91-106.

_ and Rebecca J. Slotegraaf (1999), "The Contingency Value of Complementary Capabilities in Product Development," Journal of Marketing Research, 36 (May), 239-57.

Morgan, Robert M. and Shelby D. Hunt (1994), "The Commitment-Trust Theory of Relationship Marketing," Journal of Marketing, 58 (July), 20-38.

Murry, John P., Jr., and Jan B. Heide (1998), "Managing Promotion Program Participation Within Manufacturer-Retailer Relationships," Journal of Marketing, 62 (January), 58-68.

Nonaka, Ikujiro (1994), "A Dynamic Theory of Organization Knowledge Creation," Organization Science, 5 (February), 14-37.

Noordewier, Thomas G., George John, and John R. Nevin (1990), "Performance Outcomes of Purchasing Arrangements in Industrial Buyer-Vendor Relationships," Journal of Marketing, 54 (October), 80-93. 
Nunnally, Jum C. and Ira H. Bernstein (1994), Psychometric Theory, $3 \mathrm{~d}$ ed. New York: McGraw-Hill.

Sinkula, James M. (1994), "Marketing Information Processing and Organizational Learning," Journal of Marketing, 58 (January), 34-45.

, William E. Baker, and Thomas Noordewier (1997), "A Framework for Market-Based Organizational Learning: Linking Values, Knowledge, and Behavior," Journal of the Academy of Marketing Science, 25 (Fall), 305-318.

Slater, Stanley F. and John C. Narver (1995), "Market Orientation and the Learning Organization," Journal of Marketing, 59 (July), 63-74.

Slotegraaf, Rebecca (1999), "Market Knowledge Management," Conference Summary Report No. 99-102, Marketing Science Institute.

Srivastava, Rajendra K., Tasadduq A. Shervani, and Liam Fahey (1998), "Market-Based Assets and Shareholder Value: A Framework for Analysis," Journal of Marketing, 62 (January), $2-18$.

Processes, and - (1999), "Marketing, Business Embedded View of Marketing Activities and the Discipline of Marketing," Journal of Marketing, 63 (Special Issue), 168-79.

Stern, Louis W., Brian Sternthal, and C.S. Craig (1973), "Managing Conflict in Distribution Channels: A Laboratory Study," Journal of Marketing, 10 (May), 169-79.

Sullivan, Jeremiah, Richard B. Peterson, Naoki Kameda, and Justin Shimada (1981), "The Relationship Between Conflict Resolution Approaches and Trust-A Cross Cultural Study," Academy of Management Journal, 24 (December), 803-815.
Teece, David J., Gary Pisano, and Amy Shuen (1997), "Dynamic Capabilities and Strategic Management," Strategic Management Journal, 18 (August), 509-533.

Uzzi, Brian and James J. Gillespie (2002), "Knowledge Spillover in Corporate Financing Networks: Embeddedness and the Firm's Debt," Strategic Management Journal, 23 (July), 595-618.

Walsh, James P. and Gerardo Rivera Ungson (1991), "Organizational Memory," Academy of Management Review, 16 (January), 57-91.

Watts, Charles A., Kee Young Kim, and Chan K. Hahn (1992), "Linking Purchasing to Corporate Competitive Strategy," International Journal of Purchasing and Materials Management, 28 (Fall), 2-8.

Weick, Karl E. (1995), Sensemaking in Organizations. Thousand Oaks, CA: Sage Publications.

Williamson, Oliver E. (1996), The Mechanisms of Governance. New York: Oxford University Press.

Winter, Sidney G. (1987), "Knowledge and Competence as Strategic Assets," in The Competitive Challenge: Strategies for Industrial Innovation and Renewal, David J. Teece, ed. New York: Harper and Row, 159-85.

(2000), "The Satisfying Principle in Capability Learning," Strategic Management Journal, 21 (October-November), 981-96.

Zahra, Shaker A. and Gerard George (2002), "Absorptive Capacity: A Review, Reconceptualization, and Extension," Academy of Management Review, 27 (April), 185-203. 
Copyright of Journal of Marketing is the property of American Marketing Association and its content may not be copied or emailed to multiple sites or posted to a listserv without the copyright holder's express written permission. However, users may print, download, or email articles for individual use. 